\title{
Redescription and synonymies of Diplura macrura (C.L. Koch, 1841) and $D$. lineata (Lucas, 1857), with notes on the genus (Araneae, Dipluridae)
}

\author{
Denis Rafael PEDROSO ${ }^{1, *}$, Pedro DE SOUZA CASTANHEIRA ${ }^{2} \&$ \\ Renner Luiz CERQUEIRA BAPTISTA ${ }^{3}$ \\ ${ }^{1}$ Museu Nacional, Universidade do Brasil (UFRJ). Quinta da Boa Vista, São Cristóvão, 20.940-040, \\ Rio de Janeiro, RJ, Brazil. \\ ${ }^{2,3}$ Instituto de Biologia, Universidade do Brasil (UFRJ). Avenida Brigadeiro Trompowski s/n, \\ Ilha do Fundão, 21944-970, Rio de Janeiro, RJ, Brazil. \\ ${ }^{*}$ Corresponding author: drbpedroso@gmail.com \\ ${ }^{2}$ E-mail: pedrocastanheira.bio@gmail.com \\ ${ }^{3}$ E-mail: baptistr@gmail.com \\ ${ }^{1}$ urn:1sid:zoobank.org:author:E67DAD82-2E69-4E76-B4F0-7BA09E13A68F
${ }^{2} \underline{\text { urn:1sid:zoobank.org:author:BFEC9541-C4F5-4FBF-90AB-AE4885A943D5 }}$
${ }^{3}$ urn:1sid:zoobank.org:author:CF514365-072A-4248-AF23-C112FC360305
}

Abstract. Diplura C.L. Koch, 1850 is a mygalomorph genus with putative records from Central and South America. The type-species Diplura macrura (C.L. Koch, 1841), originally described from West Indies, is poorly known and represented only by its holotype. Most of the 20 species currently included in the genus lack modern taxonomic descriptions, as D. lineata (Lucas, 1857), from Rio de Janeiro state, Brazil. Males and females of Diplura macrura and D. lineata are herein redescribed. New junior synonyms of D. macrura are identified (Linothele bicolor (Simon, 1889), Diplura uniformis MelloLeitão, 1923, and the two junior synonyms of the latter species, Thalerothele minensis Mello-Leitão, 1926 and T. aurantiaca Mello-Leitão, 1943). Also, two junior synonyms are established for D. lineata: Diplura fasciata (Bertkau, 1880) and Diplura nigridorsi (Mello-Leitão, 1924). The type-locality of D. macrura is corrected to São João del Rei, Minas Gerais state, Brazil. D. macrura is restricted to the state of Minas Gerais and D. lineata to the state of Rio de Janeiro. The type-locality of D. parallela (Mello-Leitão, 1923) is also corrected from Argentina to Paraná state, Brazil. The distribution of Diplura is now restricted from south Panama to north Argentina, excluding previous erroneous records for Cuba and West Indies. The six synonymies herein established help to clarify the genus composition, which includes now 17 valid species.

Keywords. Atlantic Forest, biodiversity, Brazil, Diplurinae, Mygalomorphae.

Pedroso D.R., Castanheira P. de Souza \& Baptista R.L.C. 2016. Redescription and synonymies of Diplura macrura (C.L. Koch, 1841) and D. lineata (Lucas, 1857), with notes on the genus (Araneae, Dipluridae). European Journal of Taxonomy 210: 1-21. http://dx.doi.org/10.5852/ejt.2016.210 


\section{Introduction}

Diplura C.L. Koch, 1850 is a Neotropical mygalomorph genus, including twenty species of variable size and color pattern. Nowadays, its accepted distribution goes from Cuba to Argentina (World Spider Catalog 2015). Most species were described from southeastern and southern Brazil, with species recorded also from the following countries: Bolivia, Ecuador, Paraguay and Venezuela.

Raven (1985) included Diplura in the subfamily Diplurinae, alongside Trechona C.L. Koch, 1850 and Linothele Karsch, 1879. The traditional diagnostic character for Diplura is the simple lyra, at the internal side of the maxilla (coxa) of the palp, formed by a single row of clavate setae (Raven 1985). In contrast, Linothele has no lyra and Trechona has a complex lyra, with multiple rows of numerous setae, arranged in a black shield. However, Harmonicon F.O. Pickard-Cambridge, 1896, included in Diplurinae by Maréchal \& Marty (1998), also has a simple lyra. In the revalidation of Harmonicon, Maréchal \& Marty (1998) proposed a separation from Diplura based on the shape and number of setae on lyra. In Harmonicon, the lyra is formed by only 5 setae, with a flattened and curved tip, whereas in Diplura it has more setae and a different tip. However, Pedroso \& Baptista (2014) pointed out that the number and shape of the setae are variable in Diplura, where some species may have just a few setae (down to 2) and setae tip curved and sometimes a bit flattened. The number of setae is not a reliable character for Harmonicon, as already suggested by Drolshagen \& Bäckstam (2011). Nevertheless, the strongly curved and flattened setal tip is found only in Harmonicon (Pedroso \& Baptista 2014). Several other characters have previously been used to separate the genera included in Diplurinae, as the tarsal scopulae and segmentation (Raven 1985) and leg formulae and size (Maréchal \& Marty 1998). A preliminary discussion on the diagnostic characters used in Diplurinae is found in Pedroso \& Baptista (2014), where several traits are dealt with. For example, the short and thickened palp tibia of males in Diplura (see Figs 5 and 17 in the plates below) strongly contrasts with the long and thin tibia in other Diplurinae, as Trechona (Pedroso et al. 2008: fig. 5), Harmonicon (Pedroso \& Baptista 2014: fig. 7) and Linothele (Duperré \& Tapia 2015: fig. 28). On the other hand, the rigid setae near lyra found in most Harmonicon species (Pedroso \& Baptista 2014: fig. 6) is diagnostic at least to a large subset of the genus.

In this paper, the composition and distribution of Diplura are discussed. The type-species Diplura macrura (C.L. Koch, 1841) is redescribed, based on the holotype and recently collected specimens. Also, the female is newly described and new synonymies are presented. The type-locality of the species is corrected to Minas Gerais state, Brazil, implying in the exclusion of Cuba and West Indies from its geographical range. Additionally, Diplura lineata (Lucas, 1857) is redescribed, two synonymies are given and the species distribution is widened. The type-locality of D. parallela (Mello-Leitão, 1923) is corrected from Argentina to Brazil.

\section{Material and methods}

The description of color pattern is based on specimens preserved in $75 \%$ ethanol. The female genitalia was cut off and clarified with clove oil. Habitat information and photos of living animals were added, when available. Observations, photographs and measurements were made with a Leica DFC295 camera, attached to a Leica M205C stereo microscope. Samples for scanning electron were coated with goldpalladium and observed under high vacuum on a JEOL JSM-6510 microscope. All photos were edited in the software Photoshop CS5 and plates were mounted in the software CorelDraw X7. Measurements are given in millimeters, unless otherwise noted. Carapace length was measured from anterior margin of the clypeus to the posterior border. Total length was measured from the anterior margin of the clypeus to the posterior border of the anal tubercle, not including the spinnerets. Each article of the pedipalp and legs was measured in retrolateral view, from the basal condylus to the distal one. Geographical coordinates for localities were obtained from Geonames (2015). The distribution map (Fig. 26) was elaborated using ESRI ARCGIS 10 software. 


\begin{abstract}
Abbreviations
Institutions

IBSP = Instituto Butantan, São Paulo, Brazil

$\mathrm{MfN}=$ Museum für Naturkunde, Berlin, Germany (formerly Zoologisch Museum für Naturkunde der Humboldt-Universität)

MLPC = Mello-Leitão's Private Collection, now at Museu Nacional, Universidade do Brasil/ Universidade Federal do Rio de Janeiro, Brazil

MNHN $=$ Muséum National d'Histoire Naturelle, Paris, France

MNRJ = Museu Nacional, Universidade do Brasil/Universidade Federal do Rio de Janeiro, Brazil

MZSP $=$ Museu de Zoologia da Universidade de São Paulo, Brazil
\end{abstract}

\title{
Structures
}

$\mathrm{ALE}=$ anterior lateral eyes

$\mathrm{AME}=$ anterior median eyes

ITC $=$ inferior (or unpaired) tarsal claws

PLE $=$ posterior lateral eyes

PLS = posterior lateral spinnerets

PME $=$ posterior median eyes

PMS $=$ posterior median spinnerets

STC $=$ superior (or paired) tarsal claws

\section{Spines (or macroseta)}

ap = apical

$\mathrm{p}=$ prolateral

pld $=$ prolaterodorsal

plv $=$ prolateroventral

$\mathrm{r}=$ retrolateral

rld $=$ retrolaterodorsal

$\mathrm{rlv}=$ retrolateroventral

$\mathrm{v}=$ ventral

\section{Results}

Class Arachnida Cuvier, 1812

Order Araneae Clerck, 1757

Family Dipluridae Simon, 1889

Genus Diplura C.L. Koch, 1850

Diplura macrura (C.L. Koch, 1841)

Figs 1-13, 26

Mygale macrura C.L. Koch, 1841: 38, fig. $715($ ふ).

Diplura bicolor Simon, 1889: 215 (ㅇ) syn. nov.

Thalerothele uniformis Mello-Leitão, 1923: 105, fig. 4 (ふ) syn. nov.

Thalerothele minensis Mello-Leitão, 1926: 314, figs 1-3 (đ) syn. nov.

Thalerothele aurantiaca Mello-Leitão, 1943: 255 (ㅇ) syn. nov.

Diplura bicolor - Mello-Leitão 1937: 3, fig. 3 (ô). - Bücherl 1957: 385, figs 12, 12a.

Diplura macrura - C.L. Koch 1850: 75. - Raven 1985: 74, figs 18-23.

Thalerothele uniformis - Bücherl, Timotheo \& Lucas 1971: 128, figs 12-14 (syn. T. minensis, T. aurantiaca). 
Diplura uniformis - Platnick 1993: 89 (transfer). — Silva-Moreira et al. 2010: 32.

Linothele bicolor - Platnick 1998: 120 (transfer).

\section{Diagnosis}

Both sexes of this species have a strongly contrasting color pattern, with a reddish brown carapace and a dark brown abdomen, shared only with Diplura paraguayensis (Gerschman \& Schiapelli, 1942). In mature D. macrura, the abdomen is uniformly dark brown, without spots or any visible markings. However, according to its original description (Gerschman \& Schiapelli 1942), D. paraguayensis has a blackish brown reticulate on abdomen dorsum. Moreover, the lyra of D. paraguayensis has 13 setae (Gerschman \& Schiapelli 1942: pl. ix; Schiapelli \& Gerschman 1968, fig. 7), in contrast with the 7-9 setae in D. macrura. The bulb of D. macrura (Figs 6-7) has an embolic base much larger than in D. paraguayensis (Schiapelli \& Gerschman 1968: figs 14-15). Also, the embolus is about $2 \times$ longer than the bulb in D. macrura and $3 \times$ longer in D. paraguayensis. The spermathecae of $D$. macrura has a longer and thinner stalk (Fig. 13) than the females of D. paraguayensis from Argentina (Goloboff 1982: 1). Also, the distal lobes are larger and spread over the distal third of the stalk in D. macrura, while they are smaller and concentrated in the apex in D. paraguayensis.

\section{Type material}

Mygale macrura: BRAZIL: ô, holotype, Minas Gerais, São João del Rei, [1830], Sellow, Friedrich W. (MfN 2083), examined.

Diplura bicolor: BRAZIL: 2 우 , syntypes, Minas Gerais, Catas Altas, Caraça (coll. E. Simon, MNHN AR 4932 B337), examined (photos).

Thalerothele uniformis: BRAZIL: đ, holotype, São Paulo, E. of Garbe (MZSP?, MNRJ?), not located.

Thalerothele minensis: BRAZIL: đ̂, holotype, Minas Gerais, Ouro Preto, Magalhães Gomes (MelloLeitão collection 880, MNRJ 1360), not located.

Thalerothele aurantiaca: BRAZIL: $\uparrow$, holotype, Minas Gerais, Ouro Preto/Mariana: Itacolomi, O. Leonardos (MNRJ 53945), not located.

\section{Material examined}

BRAZIL: 1 đ, Minas Gerais, Parque Nacional Serra do Cipó, R. Bertani, R. Martins, C.S. Fukushima \& M.P. Pavani leg. (MNRJ); 1 †, 2 juvs, Caeté, 11-19 Feb. 1961, P. Vanzolini, H. Britski \& N. Menezes

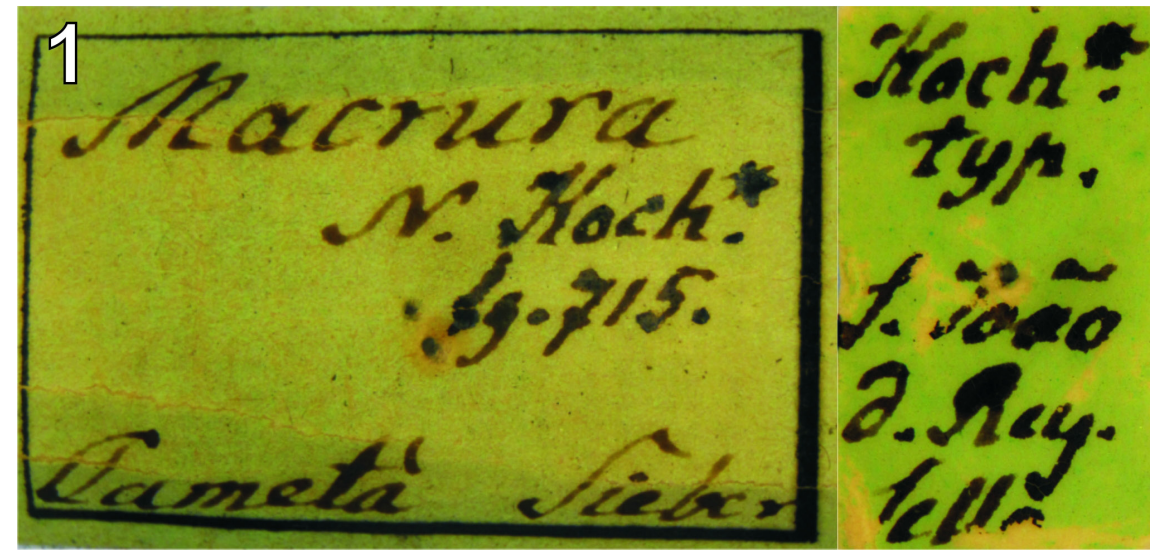

Fig. 1. Original (right) and added (left) labels from the holotype of Diplura macrura (C.L. Koch, 1841). 

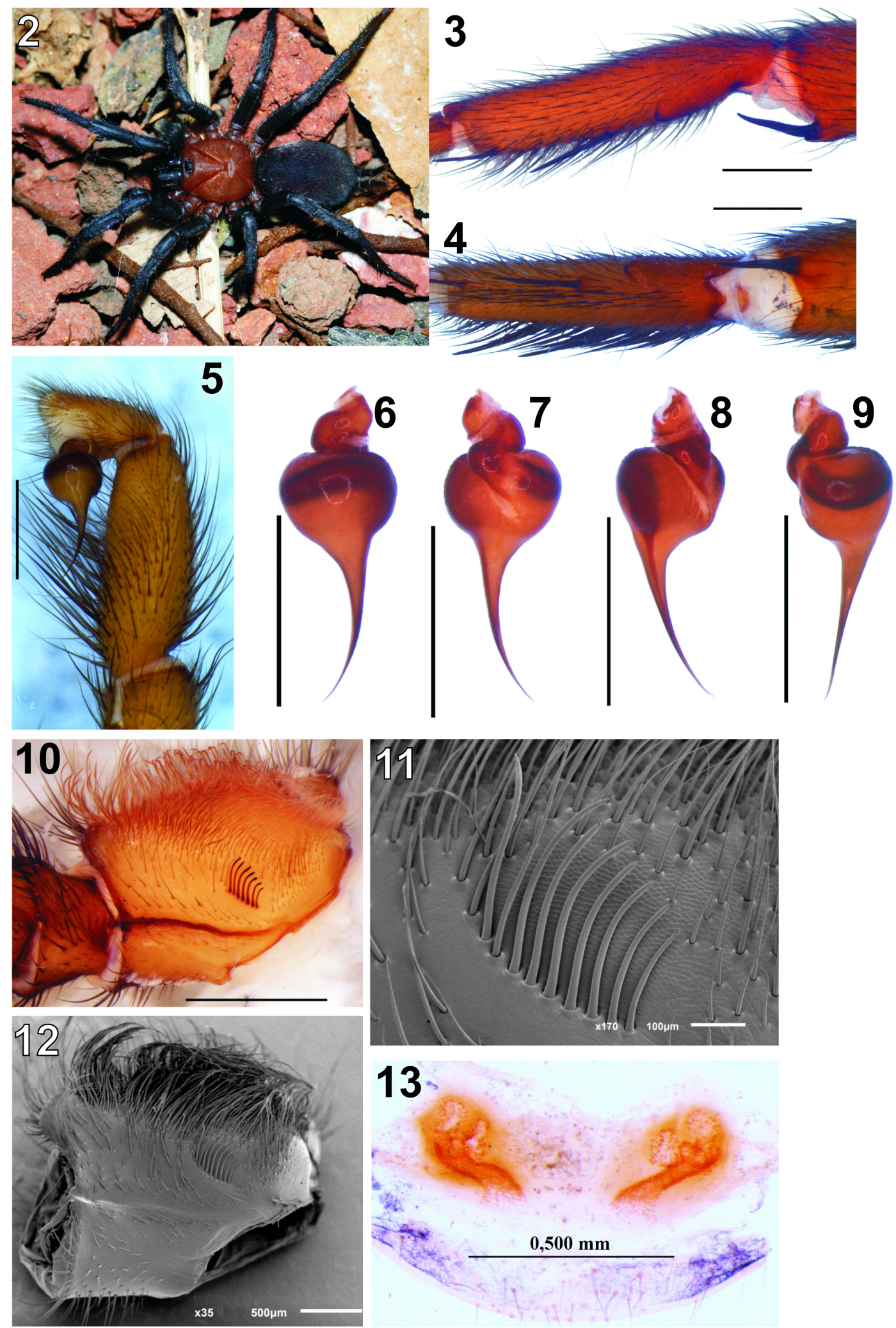

Figs 2-13. Diplura macrura (C.L. Koch, 1841). 2. + , habitus dorsal. - 3-9. Ô, left leg I. 3. Tibial spur, retrolateral. 4. Tibial spur and metatarsal clasper, ventral. 5. Left palp, retrolateral. 6-9. Left bulb. 6. Retrolateral. 7. Prolateral. 8. Ventral. 9. Dorsal. - 10-13. ․ 10. Maxilla with lyra. 11. Lyra detail, SEM. 12. Maxilla with lyra, SEM. 13. Vulva, dorsal. Scale $=1 \mathrm{~mm}$, unless otherwise noted. 
leg. (MZSP 6576); 1 , Catas Altas, Reserva Particular de Patrimônio Natural Serra do Caraça, 24 Apr.-

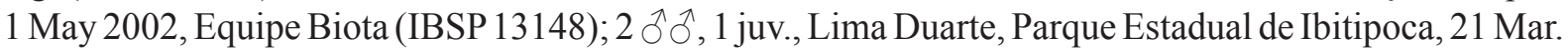
1997, A. Oliveira \& B. Souza leg. (IBSP 8390); 1 đ, Parque Estadual de Ibitipoca, Apr. 1997, A. Oliveira \& B. Souza leg. (IBSP 8432); 1 q, juv., Ouro Preto, Estação Ecológica de Tripuí, R. Bertani, R. Martins, C.S. Fukushima \& M.P. Pavani leg. (MNRJ 4467 and MNRJ 4490, respectively); 1 q, Estação Ecológica de Tripuí, 1220 m, 20²2'92.7" S, 4333'29.3" W, R. Bertani, R. Martins, C.S. Fukushima \& M.P. Pavani leg. (MNRJ 4502); 1 ð̂, Estação Ecológica de Tripuí, 1236 m, 20²2'93.2" S, 43³3'28.7" W, R. Bertani, R. Martins, C.S. Fukushima \& M.P. Pavani leg. (MNRJ 4496); 1 क (MNRJ 4487), 1 ○ (MNRJ 4497),

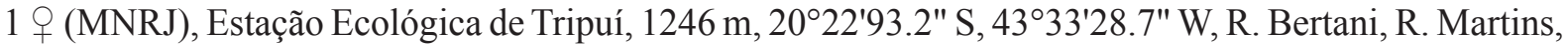
C.S. Fukushima \& M.P. Pavani leg.; 1 + Estação Ecológica de Tripuí, 20²2'6.62" S, 43³2'5.74" W, R. Bertani, R. Martins, C.S. Fukushima \& M.P. Pavani leg. (MNRJ 4509); 1 juv., Estação Ecológica de Tripuí, 20²2'9.70" S, 43³3'1.04" W, R. Bertani, R. Martins, C.S. Fukushima \& M.P. Pavani leg. (MNRJ 4498); 1 q, Estação Ecológica de Tripuí, 20²2'915" S, 43³3'227" W, R. Bertani, R. Martins, C.S. Fukushima \& M.P. Pavani leg. (MNRJ 4489); 1 đ̃, Estação Ecológica de Tripuí, 20²2'93.2" S, 43³3'26.7" W, R. Bertani, R. Martins, C.S. Fukushima \& M.P. Pavani leg. (MNRJ 4505); 1 ठ̃, Estação Ecológica de Tripuí, 20²2'93.2" S, 4333'28.7" W, R. Bertani, R. Martins, C.S. Fukushima \& M.P. Pavani leg. (MNRJ 4479); 1 juv., Estação Ecológica de Tripuí, 20²2'93.2" S, 43³3'28.7" W, R. Bertani, R. Martins, C.S. Fukushima \& M.P. Pavani leg. (MNRJ ); 1 juv., Estação Ecológica de Tripuí, 20²2'970" S, 43³3'104" W, R. Bertani, R. Martins, C.S. Fukushima \& M.P. Pavani leg. (MNRJ 4492); 1 ô, Estação Ecológica de Tripuí, 20²2'92,2" S, 4333'13" W, 8 Jan. 2006, R. Bertani, R. Martins, C.S. Fukushima \& M.P. Pavani leg. (MNRJ ); 1 q, Estação Ecológica de Tripuí, 20²2'93.2" S, 43³3'287" W, 7 Jan. 2005, R. Bertani, R. Martins, C.S. Fukushima \& M.P. Pavani M. leg. (MNRJ 4333); Ouro Preto: 1 juv., Parque Estadual do Itacolomi, R. Bertani, R. Martins, C.S. Fukushima \& M.P. Pavani leg. (MNRJ); 1 juv., Parque Estadual do Itacolomi, R. Bertani, R. Martins, C.S. Fukushima \& M.P. Pavani leg. (MNRJ

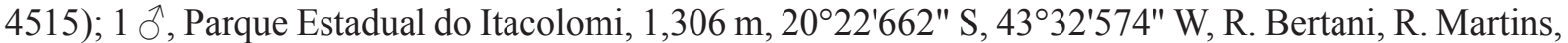
C.S. Fukushima \& M.P. Pavani leg. (MNRJ 4495); 1 क , Parque Estadual do Itacolomi, 20²5'638" S, 43³0'399" W, R. Bertani, R. Martins, C.S. Fukushima \& M.P. Pavani leg. (MNRJ 4507).

\section{Description}

Male (MNRJ 4496) (Figs 3-9)

Carapace: 6.4 long, 5.0 wide. Abdomen: 6.6 long. Spinnerets: PMS 1.3 long; PLS, total length 6.8, basal article 2.0, middle 2.2, distal 2.6, respectively. Legs: see Table 1. Carapace: length/width 1.3; flat, cephalic area slightly raised, thoracic furrows shallow and wide. Fovea: short, deep, recurved. Carapace covered with short, thin setae, interspersed with some longer and thicker setae; border with abundant long and thick setae pointing outwards, increasing in number towards posterior angles. Clypeus almost totally hidden by the bulging eye tubercle, frontal margin bearing 5 thick, long, erect setae. Eye tubercle: 0.6 long, 1.0 wide, area between posterior eyes covered with thin setae and bearing 4 thicker, longer setae. AME 0.3, almost spherical, but a bit longer than wide, set apart by $0.7 \times$ their diameter. ALE elliptical, much longer than wide, its length about $0.6 \times$ the AME diameter. PME small, with flattened lens, longer than wide, its length about $0.5 \times$ AME diameter. PLE elliptical, much longer than wide, its length a bit less than $0.7 \times$ AME diameter. PME and PLE clearly set apart by around $0.4 \times$ the PME length. Anterior eye row slightly recurved, posterior eye row recurved. Eye rows with similar width. Chelicerae: promargin with 11 teeth on left and 9 on right chelicera. Plectrum with 5 thick, long setae. Labium: length/width 0.8 , no cuspules. Labio-sternal groove deep with elongated sigilla. Sternum: about $45 \%$ longer than wide, very similar to the sternum of $D$. lineata. Posterior angle in a blunt point, not separating coxae IV. Sigilla: three pairs, spherical, with a subtle increase in size from anterior to posterior, all near margin. Palp (Fig. 5): relatively short, without retrolateral spines, femur: d1-2-0, p10-0-1, tibia pl 0-1-0, v1-2-0. Tibia: length 2.3, width 0.9 , short, incrassated, thinner at the basis and apex. Maxillae: length/width 1.5. Cuspules: 13 spread over ventral inner heel. Lyra at the ventral side of the maxilla, formed by 8 modified thick, long setae, increasing in size from basis to apex of the lyra, 
Table 1. Diplura macrura (C.L. Koch, 1841), ô. Length of left leg articles (dorsal view).

\begin{tabular}{ccccc}
\hline & Leg I & Leg II & Leg III & Leg IV \\
\hline Fe & 5.5 & 5.1 & 4.7 & 5.9 \\
Pa & 3.2 & 2.9 & 2.4 & 2.5 \\
Ti & 4.2 & 3.8 & 3.2 & 4.4 \\
Mt & 4.0 & 4.1 & 4.4 & 6.2 \\
Ta & 3.3 & 3.2 & 3.1 & 3.6 \\
Total & 20.2 & 19.1 & 17.8 & 22.6 \\
\hline
\end{tabular}

weakly curved at apical portion. Legs: Leg formula 4123. Legs covered with short, thin, horizontal black setae and with some longer, thicker, erect black setae. All tarsi with thin scopula, throughout the length of the article, divided by two series of thicker setae at the middle line of the ventral face. Metatarsus I with undivided thin scopula, covering the distal half of the retrolateral side. Metatarsus II similar to I, but with scopula on both sides. Metatarsi III-IV without scopula. All tarsi provided with numerous small cracks covering almost all the ventral and lateral faces, except by the basis and tip of the article. Leg I (Figs 3-4): tibia I with a relatively short distal retrolateral spur, curved and blunt, placed at its ventral corner. Megaspine pointed, slightly sinuous, especially on the apex, almost $2 x$ longer than the spur. Metatarsus I with a distinct retrolateral tubercle placed ventrally at the beginning of the median third, conical, pointed and facing towards the tip of article. Ventrally, there is one spine near the apex and another one on the median third, placed much ahead of the tubercle. Fringe formed by many thick and long spiniform setae and spines (clasper) covering almost all prolateral side of the metatarsus (Fig. 4). Spines: leg I: femur d1-2-0, pld0-0-1, rld0-0-1, patella p0-0-1 left, p0 right, r0 left, $0-1-0$ right, tibia p0-2-0, v0-1-1ap (apophysis), metatarsus p0-2-0, v0-1-1ap; leg II: femur d1-2-0, pld1-0-1 left, pld0-0 - 1 right, rld0-0-1 left, rld0 right, patella p0-1-1 left, p0-0-1 right, tibia p0-2-0, v1-1-2ap left, v1-0-2ap right, metatarsus p1-1-1 left, p1-1-0 right, v1-2-2ap left, v1-2-1 ap; leg III: femur d1-2-0, pld0 left, pld0-1-1 right, rld0-1-1 left, rld0-2-1 right, patella p0-1-1 left, p0-1-1 right, r0-1-0 left, r1-1-0 right, tibia p0-2-0 left, $\mathrm{p} 0-2-1$ right, $\mathrm{r} 1-1-1$, v1-1-2ap; metatarsus $\mathrm{p} 2-2-1$ left, $\mathrm{p} 0-4-1$ right, r1-1-1 left, r1-2-1 right, v0-4-3ap left, v0-3-3ap right; leg IV: femur d2-1-0 left, d1-2-0 right, rld0$0-1$ left, rld0-0-2 right, patella $\mathrm{r} 0-1-0$, tibia $\mathrm{p} 0-1-0$ left, $\mathrm{p} 0-2-0$ right, $\mathrm{r} 1-2-1$ left, $\mathrm{r} 1-1-1$ right, $\mathrm{v} 2-$ 1-2ap left, v1-0-2ap right, metatarsus d1-0-0 left, d1-1-0 right, p1-2-1, r1-2-1, v1-5-3ap. Claws: ITC without teeth. Teeth at STC: all claws with a small spur at the basis in both sides leg I: inner 6-7 and outer rows 5-6; leg II: inner row 9, outer row 8-9; leg III: inner row 6-7, outer row 6; leg IV: inner and outer rows 6-7. Bulb (Figs 6-9): piriform and conical in a retrolateral view, with length about $3 / 4$ of its width. Embolus about $2 \times$ longer than the bulb itself, with a wide base in relation to the globose part of the bulb and tapering towards the apex. Embolus clearly curved since its base and tapering from the basal third to the apex, clearly seen both on retrolateral and prolateral views. However, in dorsal view, the embolus is just slanted, almost straight. On ventral view, spermatic duct large at the base, tapering regularly towards the tip, but much thinner from the distal third on.

Female (MNRJ 4487) (Figs 2, 10-13)

Total length 15.3. Carapace: 7.3 long, 5.8 wide. Abdomen: 8.0 long, 5.0 wide. Spinnerets: PMS 1.4 long; PLS, total length 5.9, basal article 2.3, middle 1.6, distal 2.0, respectively. Legs: see Table 2. Females are very similar to males except by its bigger size and the following characteristics: carapace length/ 
Table 2. Diplura macrura (C.L. Koch, 1841),, . Length of left leg articles (dorsal view).

\begin{tabular}{ccccc}
\hline & Leg I & Leg II & Leg III & Leg IV \\
\hline Fe & 5.6 & 4.8 & 4.4 & 5.2 \\
Pa & 3.4 & 3.0 & 2.6 & 2.9 \\
Ti & 3.6 & 3.3 & 3.0 & 4.2 \\
Mt & 4.0 & 3.5 & 4.2 & 5.6 \\
Ta & 3.0 & 2.8 & 2.8 & 3.0 \\
Total & 19.6 & 17.4 & 17.0 & 20.9 \\
\hline
\end{tabular}

width 1.3. Clypeus very narrow, with the frontal margin carrying five thick, long setae, facing forward. Eye tubercle with a thick seta on its anterior margin. Area between eyes with two longer and thicker setae. AME separated by around their diameter. PME and PLE less separated. Chelicera with 10-11 promarginal teeth, on the right and left chelicera, respectively. Plectrum with 6 thick, long setae. Maxilla with 16 (left) or 19 (right) cuspules. Lyra (Figs 10-11) as in male, formed by 7 modified setae. Tarsi I-II with scopula similar to male, but tarsus III with a very thin scopula and tarsus IV without scopula. Metatarsi I-II with undivided thin scopula, covering both sides and the ventral face. All tarsi provided with few small cracks covering only the median area of the ventral and lateral faces. Spines: leg I: femur d1-2-0, pld0-0-1; patella 0 ; tibia p0-0-1, v0-0-2ap (apophysis); metatarsus v0-3-2ap; leg II: femur d1-1-0, pld0-0-1; patella p0-0-1; tibia p0-0-1, v0-0-2ap; metatarsus v0-3-2ap; leg III: femur $\mathrm{d} 1-0-0$, rld0-0-2 left, rld0-0-1 right; patella $\mathrm{p} 0-1-1$ left, $\mathrm{r} 0-1-0$; tibia $\mathrm{p} 1-1-0$ left, $\mathrm{p} 0-2-0$ right, r0-2-0, v0-0-1ap left, v0-0-2ap right; metatarsus p1-2-1 left, p1-3-1 right, r1-1-1, v0-4-3ap; leg IV: femur d1-1-0 left, d1-2-0 right, rld0-0-1; patella r0-1-0; tibia p1-1-0, r2-1-0, v0-0-1ap left, $\mathrm{v}-0-$ 0-2ap right; metatarsus $\mathrm{p} 0-2-1$ left, $\mathrm{p} 1-2-1$ right, $\mathrm{r} 2-1-2$ left, $\mathrm{r} 1-1-2$ right, $\mathrm{v} 1-3-2$ ap. Spermathecae (Fig. 13): separated by about $70 \%$ of its length, with a thick stem, keeping a similar width up to the distal lobules. Stem curved forward from the median part on, bearing three large apical lobules of variable sizes.

\section{Color pattern}

Both sexes with carapace reddish brown, covered by abundant setae of a weakly coppery hue. Thoracic furrows and cephalic area darker. Eye area black. Legs, palps, chelicera and spinnerets dark brown, with a clear contrast to the color of carapace. Labium, sternum and leg coxae orange, with darker sigilla. Dorsum of the abdomen uniformly dark brown without markings or stripes, venter usually lighter colored than dorsum, but with a dark hue in some males.

\section{Variation}

Chelicera with 8-11 promarginal teeth. Lyra at the ventral side of the maxilla, formed by 7 to 9 modified setae (Figs 10-12). The maxillary cuspules may vary from 13 to 17 in males and from 16 to 19 in females.

\section{Synonymy and notes}

When describing Mygale macrura, C.L. Koch (1841: 39) indicated that the type-locality of the species was "WestIndien, St. Juan". Nine years later, he transferred the species to his new genus Diplura, without mentioning the type-locality (C.L. Koch 1850: 75). The type-locality indicated by Koch 1841 was cited differently by subsequent authors, for example, "Westindien" (Ausserer 1871: 178), "St. Jean, 
Antilles" (Simon 1903: 963), "West Indies" (Petrunkevitch 1911: 60), or "Saint John, U.S. Virgin Islands" (Muchmore 1993: 32). All those subsequent authors did not mention any additional specimen of D. macrura and were certainly restating the information given by C.L. Koch (1841).

Banks (1909: 155) was the first arachnologist to record D. macrura in Cuba, from Pinar Del Rio, as "Ischnothele macrura Koch", but he made no comments on the implicit genus transfer, nor did he include any description of the specimens he examined. Lutz (1915: 77) and Petrunkevitch (1926: 27) also pointed out that $D$. macrura had previously been recorded from Cuba. While Lutz expressly cited Banks (1909), Petrunkevitch did not mention its source. However, he was probably also citing Banks (1909), as he stated that "Diplura macrura C. Koch, has been also reported from Cuba". In his paper on endemic spiders from Cuba, Alayón (2000: 38) also included D. macrura without any further comment. Currently, the only record for D. macrura included in the World Spider Catalog (2015) is Cuba, without any mention of Koch's type-locality.

In her paper on Cuban spiders though, Bryant (1940: 260) considered Banks' record a misidentification of Ischnothele longicauda Franganillo, 1936. She based her opinion on the relative abundance of the latter species in Cuba. The family Dipluridae is scarcely represented in Cuba, with only I. longicauda and two species of Masteria L. Koch, 1873 recorded for the country (World Spider Catalog 2015), not considering the erroneous D. macrura citation by Banks. Therefore, the only specimen of D. macrura undoubtedly cited for Cuba, West Indies or any other Caribbean locality is the holotype.

Surprisingly, an analysis of the holotype of D. macrura indicates that the type-locality was misinterpreted by Koch. The holotype label clearly indicates "Koch *. typ. S. João d. Rey. Sello" (Fig. 1, right). On the other hand, there is an additional label (Fig. 1, left) inside the vial that contains the type indicating "Macrura N. Koch. * fg. 715. Cametá Sieber", referring to Cametá, a locality in the state of Pará, northern Brazil. This additional label was probably wrongly added later in the vial, as there are no records for D. macrura from Pará. Up to now, all the specimens of D. macrura we examined came only from the state of Minas Gerais. Therefore, it is clear that the type-locality is really São João del Rei, central Minas Gerais state, Brazil. Friedrich Sellow (or Sello, 1789-1831), a famous Prussian naturalist, collected a large number of zoological specimens in Minas Gerais state, such as insects (Papavero 1973) and birds (Rego et al. 2013). Furthermore, most of Sellow's specimens are also deposited at MfN.

Diplura bicolor was described from Caraça, Minas Gerais State, Brazil, based on two female syntypes (Simon 1889: 215). It is, currently, placed in the genus Linothele, although it was considered a Diplura by former authors (Mello-Leitão 1937; Bücherl 1957). This species was implicitly transferred to its current genus following Raven (1985: 182): "all alyrate Diplurinae [...] are transferred to Linothele". As Simon (1889: 215) had not cited a lyra in his description, Diplura bicolor was regarded as a Linothele in all later spider catalogs (e.g., World Spider Catalog 2015). Notwithstanding the fact that the first description of a lyra in the maxilla of Dipluridae was made by Blackwall (1867), this structure was not mentioned again until the reevaluation of its form and function by Pocock (1896). So it is clear that Simon and other former authors had not dissected the maxilla of their specimens in search for a lyra. We have only been able to analyze photos of one syntype of Linothele bicolor (Dipluridae Contributors, 2016), as it is currently in loan to another researcher, but the photos clearly show a lyra formed by 8 setae. Simon (1889: 216) clearly cited the characteristic contrasting color pattern found in D. macrura in the original description of D. bicolor. However, he also cited some light brown spots scattered on the posterior half of the abdomen. It is possible that the syntypes cited by Simon are immature or small mature females (15.3 $\mathrm{mm}$ long) since isolated light brown spots on the sides of the abdomen are usually found only in immatures of D. macrura, disappearing in older males and females. Besides the syntype photos, the examination of other specimens of D. bicolor from its type-locality (Caraça, Catas Altas) and nearby areas of Minas Gerais state allow the clear recognition of the species. The examined specimens 
agree very well to the original description of $D$. bicolor in color and size, except by the presence of a lyra. Furthermore, despite several collections on Caraça and other nearby localities, including extensive search for Mygalomorphae, we and other researchers had not been able to find any other Diplura or Linothele species from the same region. The comparison of the above cited specimens with D. macrura from central Minas Gerais state allowed us to establish this synonymy, based on the similar color pattern and lyra.

The male of D. bicolor was supposedly described by Mello-Leitão (1937: 3, fig. 3) and Bücherl (1957: 385, fig. 12-12a). However, both specimens clearly belong to other species. We were able to examine the "allotypus" of D. bicolor described by Mello-Leitão, from Gustavo da Silveira, Minas Gerais state (IBSP 3452). It is a male of an undetermined species of Nemesiidae, with a distinctive copulatory bulb and a very setose pedipalp (Mello-Leitão 1937: fig. 3). Likewise, judging by the figures 12 and 12a by Bücherl 1957, the male he identified as D. bicolor is actually a Theraphosidae, with the typical two lobed tibial spur in leg I (Bücherl 1957: fig. 12a) and a copulatory bulb also characteristic of that family (Bücherl 1957: fig. 12).

Diplura uniformis (Mello-Leitão, 1923) was originally described as Thalerothele uniformis by MelloLeitão (1923: 105). He stated that the male holotype was collected in the state of São Paulo: São Paulo, by E. Garbe, and should be deposited in Museu de Zoologia de São Paulo (MZSP, old number 321). However, Bücherl et al. (1971: 119, 122) examined a male specimen from MNRJ, collected in Ouro Preto, labeled as type of T. uniformis by Mello-Leitão [MNRJ 192, MLPC 1056]. Since they were not able to find any type material of the species in MZSP, they considered the MNRJ specimen as the holotype of T. uniformis. They also stated that the type-locality and repository cited in the description were wrong (Silva-Moreira et al. 2010: 32). Since a later examination of the MZSP collection by R. Baptista also did not produced any evidence of the holotype, we follow Bücherl et al. (1971) and Silva-Moreira et al. (2010) in considering the MNRJ specimen as the actual holotype of T. uniformis. The transfer of T. uniformis to Diplura was made by Platnick (1993) in his catalog, following Raven (1985).

Bücherl et al. (1971: 123) also considered T. minensis Mello-Leitão, 1926 and T. aurantiaca MelloLeitão, 1943, both described from Ouro Preto (Mello-Leitão 1926: 105 and 1943: 255, respectively) as synonyms of T. uniformis. Bücherl et al. (1971: 119) examined the female holotype of T. aurantiaca, collected in Itacolomi, Ouro Preto, by Othon Leonardos (MNRJ 53945), but not the male holotype of $T$ minensis. In the description of Thalerothele minensis, it is stated that the holotype received the number MLPC 880. However, this number belongs to a type specimen of Opiliones, as Mello-Leitão wrote down in the catalogue of the part [or whole?] of his private collection purchased by MNRJ in 1929 (Kury \& Baptista 2004). Probably the wrong number in the original description was a misprint or a lapse (Silva-Moreira et al. 2010: 32).

Unfortunately, we were not able to find any Diplura material from Ouro Preto in MNRJ collection, despite several attempts. Thus, the MNRJ specimen Bücherl et al. (1971) considered as the holotype of T. uniformis and the female holotype of T. aurantiaca had also been probably lost later on. We follow Bücherl et al. (1971) on the synonymies of T. minensis and T. aurantiaca with D. uniformis, considering that all species were described from Ouro Preto and the original descriptions do not allow the recognition of any diagnostic trait. T. minensis was diagnosed in relation to T. uniformis ( $=D$. macrura) by MelloLeitão (1926: 11) based on the uniformly dark color of the abdomen, 7 setae on lyra and only 5 teeth on the promargin of chelicera. Nevertheless, the coloration of the venter in D. macrura males vary from a light hue to a dark color similar to dorsum, the number of setae on lyra varies between 7 to 9 and the number of cheliceral teeth varies from 8 to 11 . The last character is a not reliable one, as it may be variable even in one specimen, as the 9 and 11 teeth on different sides of the male herein redescribed demonstrate. The illustrations of the holotype of T. minensis by Mello-Leitão (1926: figs 1-3) are poorly 
done and not diagnostic. The similarity in color, size and lyra structure indicates that it really is a synonym of D. macrura.

T. aurantiaca is just the female of $T$. uniformis (=D. macrura), with the same color pattern and similar size as the males. Among the characters mentioned in the original description, only the 6 setae on lyra fall out of the range for D. macrura (7 to 9). However, the first seta in the lyra is smaller and thinner than the others (Fig. 10) and the number of setae increases over age. Therefore, it is probable that the 6 setae may represent a normal variation or indicate that the holotype was a small young female. The holotype vulva poorly illustrated by Bücherl et al. (1971: fig. 12) does not seem to be fully developed. Apart from the reasons mentioned above, only one species has been collected in Ouro Preto, in spite of many collecting trips resulting in abundant specimens of $D$. macrura. Notwithstanding the loss of the types of the three species from Ouro Preto, the synonymies also avoid the proliferation of nomina dubia. We compared specimens of Ouro Preto with specimens of D. macrura and this examination indicated that they all belong to the same species, as they share the same color pattern, structure of lyra and shape of male and female genitalia.

\section{Habitat notes}

D. macrura specimens have been found under fallen logs and rocks in relatively dry areas of Atlantic Forest or Cerrado vs Atlantic Forest ecotones. The spiders do not make funnel-webs, but applies silk to the ground or log cavities, sometimes building small entrance silk tubes.

Distribution (Fig. 26)

Known only from localities in central and south Minas Gerais state, Brazil.

Diplura lineata (Lucas, 1857)

Figs 14-26

Mygale lineata Lucas, 1857: 14, fig. 1a-c (ð)).

Thalerothele fasciata Bertkau, 1880: 24, pl. 1, f. 6 () syn. nov.!

Harmonicon nigridorsi Mello-Leitão, 1924: 186 () syn. nov.!

Diplura fasciata - Simon 1889: 183.

Thalerothele fasciata - Simon 1903: 963. — Mello-Leitão 1923: 101, f. 10.

Thalerothele lineata - Mello-Leitão 1926: 309.

Harmonicon nigridorsi - Mello-Leitão 1926: 315, fig. 4. — Bücherl et al. 1971: 122, figs 15-16 (§)).

Paraharmonicon nigridorsi - Mello-Leitão 1926: 316 (tentative superfluous name only).

\section{Type material}

Mygale lineata: BRAZIL, Rio de Janeiro: Rio de Janeiro, [no date], near Rio ["environs de Rio", probably Tijuca] ( $\overbrace{}^{\lambda}$ holotype, MNHN, not located).

Thalerothele fasciata: BRAZIL, Rio de Janeiro, Tijuca [no date], van Beneden leg. ( $q$ holotype, IRSNB, not located).

Harmonicon nigridorsi: BRAZIL, Rio de Janeiro, [no date], W.S. Bristowe leg. ( $q$ holotype $+\widehat{\delta}$ probably mixed later, MNRJ 17 , MLPC 847 , examined).

\section{Material Examined}

BRASIL: $2 \hat{\jmath} \hat{o}, 1$ q, 1 juv., Rio de Janeiro, Casimiro de Abreu: Barra de São João, Morro de São João, 21-24 Mar. 2003, Expedition Arachné (MNRJ 4322); 1 †, 24 Mar. 2003, Expedition Arachné (MNRJ 
Table 3. Diplura lineata (Lucas, 1857), §̂. Length of left leg articles (dorsal view).

\begin{tabular}{ccccc}
\hline & Leg I & Leg II & Leg III & Leg IV \\
\hline Fe & 6.7 & 6.4 & 6.0 & 7.6 \\
Pa & 4.0 & 3.3 & 2.8 & 3.2 \\
Ti & 5.6 & 5.3 & 4.7 & 6.1 \\
Mt & 5.3 & 5.9 & 6.6 & 9.1 \\
Ta & 5.0 & 4.6 & 4.0 & 5.0 \\
Total & 26.6 & 25.5 & 24.1 & 31.1 \\
\hline
\end{tabular}

4335); Mangaratiba: 1 đ̂, 1 †, Ilha de Itacuruçá, Águas Lindas, 24-25 Mar. 2007, R.L.C. Baptista, C.S. Costa \& A.R. Oliveira leg. (UFRJ 0332); 1 juv., Reserva Ecológica Rio das Pedras, 1112 Nov. 2004, A.P.L. Giupponi leg. (MNRJ 4312); 1 juv., Nova Iguaçu: Parque Municipal de Nova Iguaçu, 21 Jul. 2004, C. Lima leg. (MNRJ); 1 ð̊, PM Nova Iguaçu, (MNRJ 4311); 1 + , Rio de Janeiro, Parque Estadual da Pedra Branca, (MNRJ 4310); 1 क, Camorim, Açude, 31 Mar. 2014, P. Castanheira leg. (MNRJ 6820); 1 ð̄, Serra do Mendanha, 485 m, Pitfall, 12 Dec. 2008, J.A.L. Pontes leg. (MNRJ 18434); 1 ㅇ, Floresta da Tijuca, 20 Apr. 1986, R.L.C. Baptista leg. (MNRJ 3112 [CRB T005]); 1 q, 1 juv., Floresta da Tijuca, 400 m, 27 Nov. 1987, A.P.L. Giupponi leg. (MNRJ 3410); 1 9, Floresta da Tijuca, 7 Jan. 1998, A.P.L. Giupponi leg. (MNRJ 1854); 1 ㅇ, Floresta da Tijuca, 400 m, 3 Mar. 2001, A.P.L. Giupponi, D.R. Pedroso \& D.F. Almeida leg. (MNRJ 1856); 1 ô, Parque Nacional da Tijuca, 25 May 2001, A.P.L. Giupponi, D.R. Pedroso \& R.L.C. Baptista leg. (MNRJ 3568); 1 , , Parque Nacional da Tijuca, 10 Jan. 2005, D.R. Pedroso \& R.L.C. Baptista leg. (MNRJ 4302 [AER]); 1 + , Parque Nacional da Tijuca, 25 Aug. 2004, D.R. Pedroso \& A.P.L. Giupponi leg. (MNRJ 4308); 1 \&, Parque Nacional da Tijuca, Archer, 22 Jan. 2005, D.R. Pedroso \& A.P.L. Giupponi leg. (MNRJ 4309); 1 juv., Parque Nacional da Tijuca, Gávea, 18 Jan. 2005, D.R. Pedroso leg. (MNRJ 4307 [AER]); 2 q, , Parque Nacional da Tijuca, Gávea, 18 Jan. 2005, D.R. Pedroso leg. (MNRJ 4304); 2 q , Parque Nacional da Tijuca, Pai Ricardo, 21 Jan. 2005 D.R. Pedroso leg. (MNRJ 4305 [AER]); 1 + , Parque Nacional da Tijuca, Pai Ricardo, 21 Jan. 2005, D.R. Pedroso leg. (MNRJ 4306 [AER]); 1 \&, Parque Nacional da Tijuca, Pai Ricardo, 21 Jan. 2005, D.R. Pedroso leg. (MNRJ [AER]); 1 + , Parque Nacional da Tijuca, Sumaré, 22 Jan. 2005, D.R. Pedroso leg. (MNRJ 4303 [AER]).

\section{Diagnosis}

Both sexes of this species have a characteristic color pattern, similar to the Amazonian D. sanguinea (F.O. Pickard-Cambridge, 1896). The abdomen of both species have a dark brown dorsum bearing beige broad transversal stripes. In $D$. lineata, the stripes are short and broad, with irregular outline, covering only the side margins of the dorsum. At the sides, there are several small beige spots among and under the stripes (sometimes fused with them). On the other hand, D. sanguinea have longer and a bit thinner stripes, without connecting beige spots at the sides. The copulatory bulb is very similar in both species, but the spermatic duct is very constricted at the basis of the embolus, becoming almost filiform afterwards, in D. lineata (Fig. 20), while in D. sanguinea the constriction is small, and the basis of embolus harbors a large duct, which tapers regularly towards the apex. The spermathecae in D. lineata (Fig. 25) have a thick stem and three distal lobules, while D. sanguinea have a thin stem and six to seven distal lobules. 

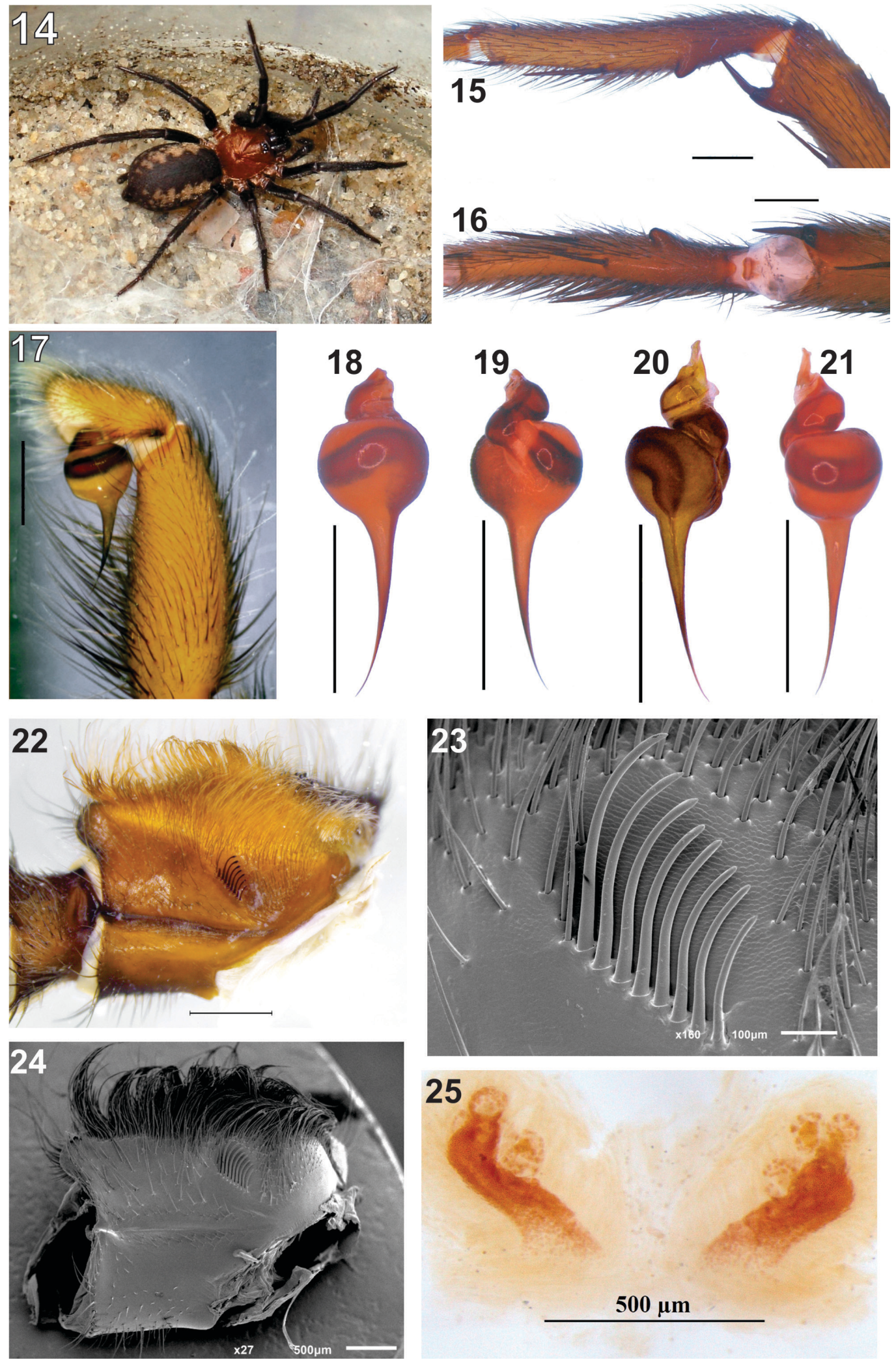

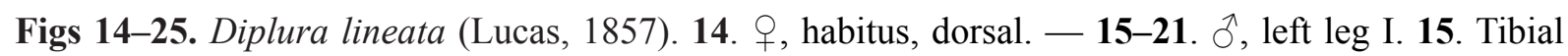
spur, retrolateral. 16. Tibial spur and metatarsal clasper, ventral. 17. Left palp, retrolateral. 18-21. Bulb detail. 18. Retrolateral. 19. Prolateral. 20. Ventral. 21. Dorsal. - 22-25. . . 22. Maxilla with lyra. 23. Lyra detail, SEM. 24. Maxilla with lyra, SEM. 25. Vulva, dorsal. Scale $=1 \mathrm{~mm}$, unless otherwise noted. 


\section{Description}

Male (MNRJ 4311)

Total length 18.5. Carapace: 7.4 long, 6.0 wide, chelicerae 2.7. Abdomen: 7.6 long, 3.9 wide. Spinnerets: PMS 0.9 long; PLS, total length 10.0, basal article 3.3, middle 3.3, distal 3.3, respectively. Legs: see Table 3. Carapace: length/width 1.2; flat, cephalic area slightly raised, thoracic furrows shallow and wide. Fovea: short, deep, slightly recurved. Carapace covered with short, thin setae, interspersed with some longer and thicker setae; border with abundant long and thick setae pointing outwards, increasing in number towards posterior angles. Clypeus narrow and small, but clearly visible, not totally hidden by the eye tubercle, frontal margin bearing 6 thick, long, erect setae. Eye tubercle: 0.5 long, 1.1 wide, one thick, long seta on tubercle anterior margin, area between posterior eyes covered with thin setae and bearing 3 thicker, longer setae. AME 0.3, almost spherical, but a bit longer than wide, set apart by half its diameter. ALE elliptical, much longer than wide, just a bit longer than the AME diameter. PME small, with flattened lens, longer than wide, its length around $0.6 \times$ AME diameter. PLE elliptical, much longer than wide, its length a bit less than $0.9 \times$ AME diameter. PME and PLE closely spaced by around $0.2 \times$ the PME length. Anterior eye row slightly recurved, posterior eye row recurved. Eye rows with similar width. Chelicerae: formed by 11 teeth on promargin on both left and right chelicera. Plectrum with 4 thick, long setae. Labium: length/width 0.8 , no cuspules. Labio-sternal groove deep, with elongated sigilla. Sternal groove deep, with elongated sigilla. Sternum slightly longer than wide. Posterior angle in a blunt point, not separating coxae IV. Sigilla: three pairs, elliptical, increasing in size from anterior to posterior, all near margin. Palp (Fig. 17): relatively short, femur: d1-3-0, pl0-0-1, rl0-0-1, tibia pl 0-2-0, v0. Tibia: 3.1 long, 1.0 wide, short, incrassated, thinner at the basis and apex. Maxillae: length/ width 1.5. Cuspules: 15 spread over ventral inner heel. Lyra: located at the ventral side of the maxilla, formed by 6 modified thick setae, the basalmost much thinner and shorter than the others, which slightly increase in size from basis to apex of the lyra, all setae weakly curved at apical portion, with rounded apex. Legs (Figs 15-16): Leg formula 4123. Legs covered with short, thin, horizontal black setae and with some longer, thicker, erect black setae. All tarsi with thin scopula, throughout the length of the article. Tarsi I-III with scopula almost undivided, with only some isolated thicker setae at the middle line of the basal third of the ventral face. Tarsi IV with scopula partially divided, with thicker setae covering the basal half of the ventral face. Metatarsi I-II almost without scopula, with only a few setae near the apex. Metatarsi III-IV without scopula. All tarsi provided with numerous small cracks covering almost all the ventral and lateral faces, except by the basis and tip of the article. Tibia I around $4.3 \times$ longer than wide. Retrolateral distal spur placed at the ventral corner of tibia I, with a wide-base, bearing at its apex a pointed and almost erect megaspine, with similar length of the spur. Metatarsus I relatively long and a little sinuous on ventral view, with a protruding retrolateral tubercle, placed ventrally on its basal third, faced towards the apex of the article. Ventral side with an apical spine and two spines on the median third, the basalmost located in advance to the tubercle. Fringe formed by many spiniform setae and spines (clasper) covering the median portion of the prolateral side of metatarsus I (Fig. 16). Spines: leg I: femur d1-2-1, pld0-2-1, rld1-1-1 left, rld0-1-2 right; patella 0 left, $0-0-1$ right; tibia p0-1-1, v0-1-1ap (apophysis); metatarsus p0-1-0, v0-2-1 ap; leg II: femur d1-2-1 left, d1-2-0 right, pld02-1, rld0-2-0 left, rld0-2-1 right; patella $0-1-1$ left, $0-0-1$ right; tibia p0-1-1, v1-1-2ap; metatarsus p10-2-0, v1-2-2; leg III: femur d1-2-0, pld0-2-1, rld0-2-1 left, rld1-1-1 right; patella pld0-1-0 left, pld0-1-1 right, rld0-1-0; tibia d1-1-0 left, d0-1-0 right, $\mathrm{p} 0-1-0$ left, $\mathrm{p} 1-1-0$ right, $\mathrm{r} 0-1-1$ left, $\mathrm{r} 1-2-0$ right, v2-2-2ap; metatarsus d3-1-1 left, d2-3-2 right, p0-2-0 left, p1-1-0 right, r0-1-0; v1-3-3ap; leg IV: femur d1-2-0, pld0-2-1, rld1-2-1 left, rld0-2-1 right; patella 0-1-0 left, $0-0-1$ right, tibia $\mathrm{d} 0-1-0, \mathrm{p} 0-1-1$ left, $\mathrm{p} 0-2-0$ right, $\mathrm{r} 2-1-1$, v2-2-2; metatarsus $\mathrm{d} 2-2-2, \mathrm{p} 1-1-1, \mathrm{r} 1-1-0$, v2-3-3ap. Claws: ITC without teeth. Teeth at STC: all claws with a wide and high spur at the basis in both sides

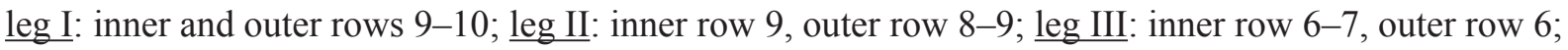
leg IV: inner and outer rows 6-7. Bulb (Figs 18-21): globose, slightly wider than long, with embolus moderately long, around $2 \times$ the bulb size. Bulb with an abrupt curve near the base of the embolus and a 
Table 4. Diplura lineata (Lucas, 1857), . . Length of left leg articles (dorsal view).

\begin{tabular}{ccccc}
\hline & Leg I & Leg II & Leg III & Leg IV \\
\hline Fe & 7.5 & 7.0 & 6.6 & 7.4 \\
Pa & 4.6 & 4.4 & 3.7 & 4.1 \\
Ti & 5.5 & 5.2 & 4.6 & 5.9 \\
Mt & 5.5 & 5.5 & 5.9 & 6.9 \\
Ta & 4.1 & 4.0 & 3.6 & 3.5 \\
Total & 27.2 & 26.1 & 24.4 & 27.8 \\
\hline
\end{tabular}

strong constriction on ventral view. Embolus with a relatively thin base, gradually tapering towards the apex, either on prolateral or retrolateral view. Embolus on ventral view slightly curved at its beginning, straight through most of its length, with the apex bended retrolaterally. Also on ventral view, a strong bulge near the base of the embolus and spermatic duct wide, abruptly tapering near the base of the embolus, becoming thinner, almost filiform.

Female (MNRJ 6820) (Fig 14)

Total length 15.3. Carapace: 6.7 long, 5.4 wide, chelicerae 2.6. Abdomen: 8.6 long, 4.9 wide. Spinnerets: PMS 1.1 long; PLS, total length 6.9, basal article 2.5, middle 2.2, distal 2.2; respectively. Legs: see Table 4. Females are very similar to males except by its bigger size and the following characteristics: carapace length/width 1.2. Clypeus narrow, around $1 / 2$ AME diameter, frontal margin with 7 setae. Eye tubercle with 4 thick setae on anterior margin, area between posterior eyes bearing 5 thick setae. 13 teeth on promargin of chelicera. Maxilla with 19 (left) and 16 (right) cuspules. Lyra (Fig. 22-24) with 8 setae. All tarsi with thin scopula, throughout the length of the article. Tarsi I-II with scopula divided by two series of thicker setae at the middle line of the ventral face, but tarsi III-IV with many setae arranged in several rows covering most of the ventral face throughout the article. Metatarsi I-II with undivided thin scopula, covering both sides and the ventral face. Metatarsi III-IV without scopula. All tarsi provided with few small cracks covering only the median area of the ventral and lateral faces. Spines: leg I: femur $\mathrm{d} 2-1-1$ left, $\mathrm{d} 1-2-0$ right; patella 0 ; tibia $\mathrm{p} 0-0-1, \mathrm{r} 0-0-1$ left, $\mathrm{r} 0$ right, $\mathrm{v} 0-0-2$; metatarsus $\mathrm{v} 0-3-2 \mathrm{ap}$; leg II: femur d1-2-0, pld0-0-1; patella 0 ; tibia p0-0-1, v0-0-2ap; metatarsus v1-2-2ap; leg III: femur d $1-0-0$ left, d0 right, pld0-0 -1 , rld0 $-0-1$ left, rld0-0 -2 right; patella r0 $-0-1$ left, $\mathrm{r} 0-1-0$ right, pld0$0-1$ right; tibia p1-2-0 left, $\mathrm{p} 0-1-0$ right, $\mathrm{r} 1-1-1$ left, $\mathrm{r} 1-2-0$ right, $\mathrm{v} 0-0-2 \mathrm{ap}$; metatarsus $\mathrm{p} 1-3-1$ left, p2-3-2 right, r1-2-1, v1-3-3ap left, v1-5-3ap right; leg IV: femur d1-2-0, rld0-0-2, patella p0-0-1, r0-1-0, tibia p0-2-0, r1-1-1, v0-1-2ap; metatarsus p1-1-0, r1-1-0, v1-2-1ap. Spermathecae (Fig. 25) separated by about $50 \%$ of its length, with a thick stem and similar width up to the distal lobules. Stem strongly bent forward at the distal third, bearing one large internal lobe just before the curvature and two apical lobules, all with similar size.

\section{Color pattern}

Both sexes with carapace reddish brown, thoracic furrows and cephalic area slightly darker, sometimes all the carapace dark reddish brown. Eye area black. Chelicera reddish brown; labium, sternum and leg coxae reddish orange brown with darker sigillae. Legs orange brown. Abdomen dark brown, bearing short and large light brown transversal stripes with irregular outlines, placed only over the flanks, many light brown spots between and underneath the stripes. Venter pale brown. 


\section{Variation}

Total length may vary from 16.2 to 18.5 in males and from 15.3 to 26 in females. Cheliceral teeth on promargin varying from 8 to 11 in both males and females. The maxillary cuspules may vary between 12 and 15 in males and 14 and 19 in females. In females, the lyra is composed by 6 to 8 setae.

\section{Synonymy and notes}

Lucas 1857 described Mygale lineata based on a male specimen from the surroundings of the city of Rio de Janeiro. The collecting locality was probably Tijuca Forest, as many foreigners had houses or farms in the area and collecting trips to other localities were not encouraged by Brazilian government. Considering the common practice in that time and the illustration of the habitus (Lucas 1857: fig. 1), the male holotype was probably dried and pinned. The small abdomen seems shrunk and folded at both sides of the dorsum, what gives an impression of a median light longitudinal stripe. The holotype may be lost, as it was not found at the MNHN collection during a visit by the first author and it was not located by the MNHN curator afterward.

Bertkau (1880) described Thalerothele fasciata based on a female from Tijuca. The holotype of this species is probably lost, like most Bertkau's type material (e.g., Levi 1969: 71, 1991: 203, 210; Höfer \& Brescovit 2000: 332). The description given by Bertkau (1880: 24) for Thalerothele fasciata, including an illustration of the female habitus (Bertkau 1880: fig. 6), is extensive. However, it does not give details of the genitalia, as Bertkau considered that it was probably an immature female (Bertkau 1880: 25). On the other hand, the illustration depicts the typical color pattern of D. lineata. The $14.5 \mathrm{~mm}$ body

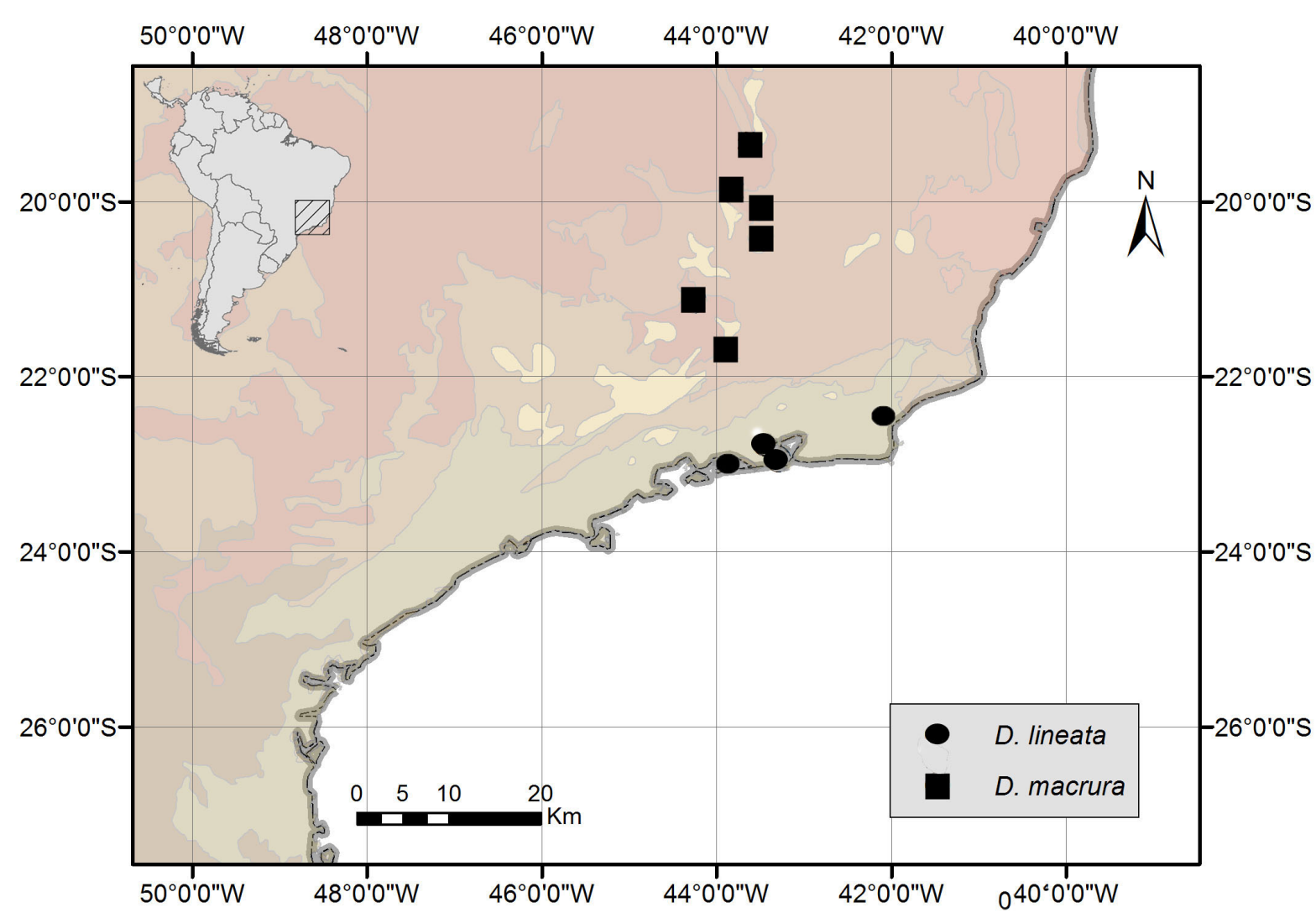

Fig. 26. Map showing the known records of Diplura macrura (C.L. Koch, 1841) and Diplura lineata (Lucas, 1857). 
length of the immature female holotype is just a little less than the 15.3 to $23.5 \mathrm{~mm}$ found in D. lineata fully grown females. There are 8 teeth on the promargin of the chelicera, what is similar to the 8 to 11 teeth in D. lineata. Compared to the range of 14-19 cuspules in D. lineata, the smaller number (6-7) of T. fasciata holotype is probably due to its small age, as immature $D$. lineata have less cuspules on maxilla and there is a well-known increase in number of cuspules with age and size in many Mygalomorphae.

Mello-Leitão (1924: 186) established Harmonicon nigridorsi (now Diplura nigridorsi) for one female holotype from the city of Rio de Janeiro. Furthermore, the redundant description of the same species (Mello-Leitão 1926: 10) also mentioned only the female holotype ("typo"). Both descriptions of Harmonicon nigridorsi (Mello-Leitão 1924, 1926) are short, without mention to genitalia or any clear diagnostic trait in relation to D. lineata. When examining the type vial (MNRJ 17, MLPC 847), we found a male from the same species, besides the female holotype. Bücherl et al. (1971: 119) considered the male "tipo" (holotype) and the female as a "síntipo" (paratype), in spite of clear indication by MelloLeitão that the holotype was a female, without mention to any additional specimen. The female holotype is badly preserved and darkened, with chelicerae, legs and most of the pedipalps separated from the body. Only the coxa (maxilla) and trochanter of the right pedipalp are still connected to the holotype body, and the maxilla of the left pedipalp is missing. Dissection of the genital area revealed an small genitalia, with lobes not completely developed, indicating that the female was not old, but show the pattern found in D. lineata (Fig. 25). The color pattern is barely visible, probably due to former events of desiccation. The original description mentioned a large dark median band on the back of abdomen, with sinuous margins, delimited by light stripes at each side. Also, there were light spots scattered over the sides. To date, the shrunk abdomen still displays the light brown transversal stripes with irregular outlines and some light brown spots underneath the stripes also found in typical $D$. lineata. The male (total length 19.5) was clearly erroneously included in the holotype vial and seems to have been collected later, as it is in a better state than the female, although also shrunk and darkened. The chelicerae, coxae and trochanter II-IV and left femur IV are still attached to the body. The severely shrunk abdomen still shows the light brown stripe as in the female. The copulatory bulb, lyra with 6 setae, tibia I retrolateral spur and metatarsus I tubercle are also similar to D. lineata. The illustration of the copulatory bulb by Bücherl et al. (1971: fig. 15) is misleading, as it depicts a very elongated and wide embolus, compared to smaller and thinner embolus found in the vial, similar to D. lineata (Figs 17-21). On the other hand, the tibia and metatarsus I in fig. 16 are accurate and similar to D. lineata (Fig. 16).

In relation to the original description, there are two numbers for the total length of the holotype of D. nigridorsi: $28 \mathrm{~mm}$ (Mello-Leitão 1924) and $23 \mathrm{~mm}$ (Mello-Leitão 1926). Probablly both numbers are wrong, but $23 \mathrm{~mm}$ falls in the range observed for females of D. lineata (15.3-26) and is closer to the current shrunk size of the holotype (13.5). Mello-Leitão cited only 8 cheliceral teeth, but there are also 3 small teeth he may have overlooked. He also cited 12-14 cuspules on the maxilla of the holotype. The inner corner of the right maxilla has 14 cuspules, but there is a scar on that area, what may indicates that the original number of cuspules was higher. Anyway, the number of teeth and cuspules both fall within the range of $D$. lineata, but there is a lot of variation in the number of those structures throughout species of Diplura. There are 5 setae in the lyra of the holotype of $D$. nigridorsi, just one less than the minimal number found in D. lineata. This is obviously just intraspecific variation, as the female is a young mature specimen. Finally, only one species of Diplura has been found in the dozens of collection trips to forested areas in Rio de Janeiro city. Following the reasons above, the three described species are considered synonyms, and $D$. lineata prevails as the senior synonym.

\section{Habitat}

Specimens of $D$. lineata have been found under fallen logs in humid areas of the Atlantic forest. The spiders do not make funnel-webs, but apply silk to the tunnels or log cavities. Sometimes they build small entrance silk tubes or connect some tubes in a small silk network inside log cavities. 


\section{Distribution (Fig. 26)}

Known only from the state of Rio de Janeiro, Brazil, restricted to the municipalities of Casimiro de Abreu, Nova Iguaçu, Rio de Janeiro and Mangaratiba. The records for Venezuela and Colombia (Simon 1889: 188) and for the state of Santa Catarina, Brazil (Mello-Leitão 1923: 101-102) are probably erroneous. The specimens cited by Simon may belong to D. sanguinea (F.O. Pickard-Cambridge, 1896) or a related species, as we have examined specimens from Colombia belonging to that species-group.

\section{Discussion}

Currently, the accepted distribution of Diplura includes Cuba, Venezuela, Ecuador, Brazil, Bolivia, Paraguay and Argentina (World Spider Catalog 2015). As discussed above, the records for D. macrura from Cuba or any other Caribbean or West Indies localities are erroneous. We have been able to examine a male of Diplura sanguinea from Arraiján: Cerro Silvestre, belonging to personal collection of Roberto Miranda. Therefore, the northernmost record known for Diplura is from a locality in central Panamá, near Panamá city. As pointed out above, Colombia should also be included in the distribution range for Diplura.

One additional remark on the distribution of Diplura is the correct type-locality of Diplura parallela (Mello-Leitão, 1923). This species is erroneously cited for Argentina in the World Spider Catalog (2015) and older catalogs. However, the holotype and only known specimen of D. parallela was collected from an unknown locality in the state of Paraná, Brazil, as Mello-Leitão (1923: 100) stated in the original description. This mistake has probably arisen from the homonymy of Paraná, a locality in the Entre-Ríos province, northern Argentina, and the state of Paraná, in southern Brazil.

Taking into account the synonymies we established in this paper, 17 valid described species remain in Diplura. Ten of the described species are recorded from Brazil, two species each from Argentina and Bolivia, and just one for Ecuador, Paraguay and Venezuela. Additionally, there are records of unidentified species from Colombia and Panamá. In summary, the revised distribution range of Diplura goes from south Panamá to north Argentina.

\section{Acknowledgments}

We thank Osvaldo Villarreal Manzanilla (MNRJ) and Adriano Brilhante Kury for the aid with the map, Marcelo Henrique de Oliveira Sales (UFRJ) by technical support on SEM photos, Ricardo Monteiro and Margarete Macedo, of the Laboratório de Ecologia de Insetos (UFRJ), and Sérgio Potsch de Carvalhoe-Silva, of the Laboratório de Herpetologia (UFRJ), for allowing the use of equipment for photos and measurements. We also thank Rogério Bertani (Instituto Butantan) for the live specimen photographs and additional samples. This work was supported by a Ph.D. grant from Fundação de Amparo à Pesquisa do Estado do Rio de Janeiro (FAPERJ).

\section{References}

Alayón G.G. 2000. Las arañas endémicas de Cuba (Arachnida: Araneae). Revista Ibérica de Aracnología 2: $1-48$.

Ausserer A. 1871. Beiträge zur Kenntnis der Arachniden-Familie der Territelariae Thorell. Verhandlungen der königlich-kaiserlichen zoologisch-botanischen Gesellschaft in Wien 21: 117-224. Available from http://biodiversitylibrary.org/page/16425408 [accessed 9 Jun. 2016]

Banks N. 1909. Arachnida of Cuba. Estación Central Agronómica de Cuba, Second Report 2: 150-174.

Bertkau P. 1880. Verzeichnis der von Prof. Ed. van Beneden auf seiner im Auftrage der Belgischen Regierung unternommen wissenschaftlichen Reise nach Brasilien und La Plata im Jahre 1872-73 
gesammelten Arachniden. Mémoires Couronnés et Mémoires des Savants Étrangers de l'Académie Royale des Sciences, des Lettres et des Beaux-Arts de Belgique 43: 1-120.

Blackwall J. 1867. Remarks on the falces and maxillae of spiders. Annals and Magazine of Natural History (3) 19: 258-259.

Bryant E.B. 1940. Cuban spiders in the Museum of Comparative Zoology. Bulletin of the Museum of Comparative Zoology at Harvard College 86: 247-532. Availbale from http://biodiversitylibrary.org/ page/2776159 [accessed 9 Jun. 2016]

Bücherl W. 1957. Sobre a importância dos bulbos copuladores e das apófises tibiais dos machos na sistemática das aranhas caranguejeiras (Orthognatha). Anais da Academia Brasileira de Ciências 29 (3): $377-416$.

Bücherl W., Timotheo da Costa A. \& Lucas S. 1971. Revisão de alguns tipos de aranhas caranguejeiras (Orthognatha) estabelecidos por Cândido de Mello-Leitão e depositados no Museu Nacional do Rio. Memórias do Instituto Butantan 35: 117-138.

Dipluridae Contributors 2016. "Dipluridae Wiki". Available from http://dipluridae.de/wiki/index. php?title=Main Page\&oldid $=5389$ [accessed 2 Feb. 2016].

Drolshagen B. \& Bäckstam C.M. 2011. Notes on the genus Harmonicon F.O.P.-Cambridge 1896 (Araneae, Dipluridae) with description of a new species from French Guyana. ZooKeys 112: 89-96. http://dx.doi.org/10.3897/ZooKeys.112.1205

Dupérré N. \& Tapia E. 2015. Descriptions of four kleptoparasitic spiders of the genus Mysmenopsis (Araneae, Mysmenidae) and their potential host spider species in the genus Linothele (Araneae, Dipluridae) from Ecuador. Zootaxa 3972 (3): 343-368. http://dx.doi.org/10.11646/zootaxa.3972.3.3

Geonames 2015. GeoNames Geographical Database. Available from http://www.geonames.org/ [accessed 11 Dec. 2015].

Gerschman B.S. \& Schiapelli R.D. 1942 [1940]. Una especie paraguaya del género Parathalerothele Canals, 1931. Revista Chilena de Historia Natural 44: 105-108.

Goloboff P. 1982. Descripción de la hembra de Achetopus paraguayensis (Gerschman y Schiapelli, 1940) Araneae Dipluridae. Physis, Revista de la Sociedad Argentina de Ciencias Naturales (Secc. C) 41: 103-105.

Höfer H. \& BrescovitA.D. 2000. Arevision of the Neotropical spider genus Ancylometes Bertkau (Araneae: Pisauridae). Insect Systematics \& Evolution 31: 323-60. http://dx.doi.org/10.1163/187631200X00075

Koch C.L. 1841. Die Arachniden. Vol. 9. C.H. Zeh'schen Buchhandlung, Nürnberg.

Koch C.L. 1850. Übersicht des Arachnidensystems. Vol. 5: 1-77. J.L. Lotzbeck Verlag, Nürnberg. Available from http://biodiversitylibrary.org/page/27438049 [accessed 10 Jun. 2016]

Kury A.B. \& Baptista R.L.C. 2004. Arachnological papers published by Cândido Firmino de MelloLeitão (Arachnida). Publicações Avulsas, Museu Nacional do Rio de Janeiro 105: 1-17.

Levi H.W. 1969. Notes on American theridiid spiders. Psyche 76 (1): 68-73. http://dx.doi. org/10.1155/1969/15815

Levi H.W. 1991. The Neotropical and Mexican species of the orb-weaver genera Araneus, Dubiepeira and Aculepeira (Araneae: Araneidae) Bulletin of the Museum of Comparative Zoology at Harvard College 152 (4): 167-315. Available from http://biodiversitylibrary.org/page/4782002 [accessed $10 \mathrm{Jun}$. 2016] 
Lucas H 1857. Arachnides. In: de Castelnau F. (ed.) Expédition dans les parties centrales de l'Amérique $d u$ Sud 3 (7): 14-23. Bertrand, Paris. Available from http://biodiversitylibrary.org/page/39510126 [accessed 10 Jun. 2016]

Lutz F.E. 1915. List of Greater Antillean Spiders, with notes on their Distribution. Annals of the New York Academy of Sciences 26: 71-148. Available from http://biodiversitylibrary.org/page/35615371 [accessed 10 Jun. 2016]

Maréchal P. \& Marty C. 1998. Réhabilitation du genre Harmonicon (Pickard Cambridge, 1896) et description d'une nouvelle espèce de Guyane Française (Araneae, Mygalomorphae, Dipluridae). Zoosystema 20: 499-504.

Mello-Leitão C.F. 1923. Theraphosoídeas do Brasil. Revista do Museu Paulista 13: 1-438. Available from http://biodiversitylibrary.org/page/48495390 [accessed 10 Jun. 2016]

Mello-Leitão C.F. 1924. Quelques arachnides nouveaux du Brésil. Annales de la Societé Entomologique de France 93: 179-187.

Mello-Leitão C.F. 1926. Algumas Theraphosoideas novas do Brasil. Revista do Museu Paulista 14: 307-324.

Mello-Leitão C.F. 1937. Aranhas novas ou raras. Anais da Academia Brasileira de Ciências 9: 1-12.

Mello-Leitão C.F. 1943. Araneologica varia brasiliana. Anais da Academia Brasileira de Ciências 15: 255-265.

Muchmore W.R. 1993. List of terrestrial invertebrates of St. John, U.S. Virgin Islands (exclusive of Acarina and Insects), with some records of freshwater species. Caribbean Journal of Sciences 29 (1-2): $30-38$.

Papavero N. 1973. Essays on the History of Neotropical Dipterology, with Special Reference to Collectors (1750-1905). Vol. 2. Museu de Zoologia, Universidade de São Paulo, São Paulo.

Pedroso D.R. \& Baptista R.L.C. 2014. A new troglomorphic species of Harmonicon (Araneae, Mygalomorphae, Dipluridae) from Pará, Brazil, with notes on the genus. ZooKeys 389: 77-88. http:// dx.doi.org/10.3897/zookeys.389.6693

Pedroso D.R., Baptista R.L.C. \& Ferreira P.S.F. 2008. Trechona rufa (Araneae, Dipluridae): new status, redescription and neotype designation with notes on the genus. Journal of Arachnology 36: 360-367. http://dx.doi.org/10.1636/CA07-109.1

Petrunkevitch A. 1911. A synonymic index-catalogue of spiders of North, Central and South America with all adjacent islands, Greenland, Bermuda, West Indies, Terra del Fuego, Galapagos, etc. Bulletin of the American Museum of Natural History 29: 1-791. Available from http://biodiversitylibrary.org/ page/26894555 [accessed 10 Jun. 2016]

Petrunkevitch A. 1926. Spiders from the Virgin Islands. Transactions of the Connecticut Academy, Arts and Sciences 28: 21-78.

Platnick N.I. 1993. Advances in Spider Taxonomy 1988-1991, with Synonymies and Transfers 19401980. New York Entomological Society, New York.

Platnick N.I. 1998. Advances in Spider Taxonomy 1992-1995 with Redescriptions 1940-1980. New York Entomological Society, New York.

Pocock R.I. 1896. On the presence of Wood Mason's stridulating organ in Trechona zebrata. Annals and Magazine of Natural History (6) 17: 177-179. http://dx.doi.org/10.1080/00222939608680344 
Raven R.J. 1985. The spider infraorder Mygalomorphae (Araneae): Cladistics and systematics. Bulletin of the American Museum of Natural History 182: 1-180.

Rego M.A., Moreira-Lima L., Silveira F. \& Frahnert S. 2013. On the ornithological collection of Friedrich Sellow in Brazil (1814-1831), with some considerations about the provenance of his specimens. Zootaxa 3616 (5): 478-484. http://dx.doi.org/10.11646/zootaxa.3616.5.4

Schiapelli R.D. \& Gerschman de P. B.S. 1968. El género Achetopus Tullgren 1905 (Araneae, Dipluridae). Physis, Revista de la Sociedad Argentina de Ciencias Naturales (C) 28: 183-192.

Silva-Moreira T. da, Baptista R.L.C., Kury A.B., Giupponi A.P.L., Buckup E.H. \& Brescovit A.D. 2010. Annotated check list of Arachnida type specimens deposited in the Museu Nacional, Rio de Janeiro. II - Araneae. Zootaxa 2588: 1-91.

Simon E. 1889. Arachnides. In: Voyage de M. E. Simon au Venezuela (Décembre 1887 - Avril 1888). 4e Mémoire. Annales de la Societé Entomologique de France (6) 9: 169-220. Available from http:// biodiversitylibrary.org/page/32438721 [accessed 10 Jun. 2016]

Simon E. 1903. Histoire Naturelle des Araignées, vol. 2 (4, Suppl. Gén.): 669-1080. Paris. Available from http://biodiversitylibrary.org/page/36005327 [accessed 22 Jun. 2016]

World Spider Catalog 2015. World Spider Catalog, version 16.5. Natural History Museum Bern. Available from http://wsc.nmbe.ch [accessed 11 Dec. 2015].

Manuscript received: 15 December 2015

Manuscript accepted: 16 March 2016

Published on: 7 July 2016

Topic editor: Rudy Jocqué

Desk editor: Kristiaan Hoedemakers

Printed versions of all papers are also deposited in the libraries of the institutes that are members of the EJT consortium: Muséum national d'Histoire naturelle, Paris, France; Botanic Garden Meise, Belgium; Royal Museum for Central Africa, Tervuren, Belgium; Natural History Museum, London, United Kingdom; Royal Belgian Institute of Natural Sciences, Brussels, Belgium; Natural History Museum of Denmark, Copenhagen, Denmark; Naturalis Biodiversity Center, Leiden, the Netherlands. 